\title{
Guidelines for the clinical management of Lynch syndrome (hereditary non-polyposis cancer)
}

\author{
H F A Vasen, G Möslein, A Alonso, I Bernstein, L Bertario, I Blanco, J Burn, G Capella, C Engel, \\ I Frayling, W Friedl, F J Hes, S Hodgson, J-P Mecklin, P Møller, F Nagengast, Y Parc, L Renkonen- \\ Sinisalo, J R Sampson, A Stormorken, J Wijnen
}

J Med Genet 2007;44:353-362. doi: 10.1136/jmg.2007.048991

Lynch syndrome (hereditary non-polyposis colorectal cancer) is characterised by the development of colorectal cancer, endometrial cancer and various other cancers, and is caused by a mutation in one of the mismatch repair genes: $M L H I, M S H 2$, MSH6 or PMS2. The discovery of these genes, 15 years ago, has led to the identification of large numbers of affected families. In April 2006, a workshop was organised by a group of European experts in hereditary gastrointestinal cancer (the Mallorca-group), aiming to establish guidelines for the clinical management of Lynch syndrome. 21 experts from nine European countries participated in this workshop. Prior to the meeting, various participants prepared the key management issues of debate according to the latest publications. A systematic literature search using Pubmed and the Cochrane Database of Systematic Reviews reference lists of retrieved articles and manual searches of relevant articles was performed. During the workshop, all recommendations were discussed in detail. Because most of the studies that form the basis for the recommendations were descriptive and/or retrospective in nature, many of them were based on expert opinion. The guidelines described in this manuscript may be helpful for the appropriate management of families with Lynch syndrome. Prospective controlled studies should be undertaken to improve further the care of these families.

See end of article for authors' affiliations

Correspondence to: Dr H F A Vasen, Department of Gastroenterology, Leiden University Medical Centre \& The Netherlands

Foundation for the

Detection of Hereditary

Tumours, Rijnsburgerweg

10, 2333 AA Leiden, The

Netherlands; hfavasen@ stoet.nl

Received 8 January 2007 Revised 12 February 2007 Accepted 14 February 2007 Published Online First 2 March 2007
- nvironmental factors play a dominant role in - the aetiology of most colorectal cancers (CRCs). - However, inherited genetic factors are also significant in between $15 \%$ and $30 \%$ of cases. In about $5 \%$ of all cases, CRC is associated with a highly penetrant dominant or recessive inherited syndrome. The most common of these is Lynch syndrome (hereditary non-polyposis colorectal cancer (HNPCC)). ${ }^{1}$ It is characterised by the development of CRC, endometrial cancer and various other cancers, and is caused by a mutation in one of the mismatch repair (MMR) genes: $M L H 1, M S H 2, M S H 6$ or PMS2. Familial adenomatous polyposis (FAP) is another well-described inherited syndrome, and is responsible for $<1 \%$ of all CRC cases. It is characterised by the development of hundreds to thousands of adenomas in the colorectum. Almost all patients develop CRC if they are not identified and treated at an early stage. FAP is transmitted as an autosomal dominant trait, and is caused by truncating mutations in the $(A P C)$ adenomatosis polyposis coli gene. Recently, the MUTYH (mutY homologue (Escherichia coli)) gene has been identified as a further polyposis gene. The associated disorder has been termed MUTYH-associated polyposis or MAP, and displays an autosomal recessive pattern of inheritance.

In April 2006, a workshop was organised by a group of European experts on hereditary gastrointestinal cancer in Palma de Mallorca. The main purpose of this meeting was to establish guidelines for the clinical management of the most common inherited forms of CRC and to identify collaborative studies. Twenty-one experts from nine European countries participated in this workshop. Prior to the meeting, various participants were requested to prepare the key management issues of debate according to the latest publications. During the workshop, all recommendations were discussed in detail. In this review, we report the outcome of the discussion with respect to Lynch syndrome.

A systematic literature search using Pubmed and the Cochrane Database of Systematic Reviews, reference lists of retrieved articles and manual searches of relevant articles was performed. Search terms included HNPCC, Lynch syndrome, microsatellite instability and MMR genes. Only peerreviewed English articles were included. Table 1 shows the criteria that were used for evaluation of studies on management, for categorisation of evidence that they presented and for the strength of the recommendations that we made.

CHARACTERISTICS OF LYNCH SYNDROME Carriers of an MMR gene mutation have a high risk of developing CRC, endometrial cancer and other associated cancers. Table 2 summarises the various types of cancers and the reported risks. ${ }^{3-10}$ The cancers observed in families with Lynch syndrome are diagnosed at an unusually early age, and may be multiple. The MMR defect leads to instability in microsatellites of tumour DNA; this is called microsatellite instability (MSI). This feature can be found in $>90 \%$ of colon cancers associated with Lynch syndrome, whereas in sporadic CRC it is found in about $15 \%$ of cases.

Abbreviations: CPT1 1, irinotecan; CRC, colorectal cancer; FAP, familial adenomatous polyposis; FU, fluorouracil; HNPCC, hereditary non-polyposis colorectal cancer; IHC, immunohistochemical; MSI, microsatellite instability; MMR, mismatch repair; QoL, quality of life; TVU, transvaginal ultrasound 
Table 1 Validity and grading of recommendations

\begin{tabular}{lll}
\hline Category of evidence & & $\begin{array}{l}\text { Grading of } \\
\text { recommendations }\end{array}$ \\
\hline Meta-analysis of randomised controlled trial & Ia & $\mathrm{A}$ \\
Randomised controlled trial & Ib & $\mathrm{B}$ \\
$\begin{array}{l}\text { Well-designed controlled study without randomisation } \\
\text { Well-designed quasi-experimental study }\end{array}$ & Ila & \\
$\begin{array}{l}\text { Non-experimental descriptive study } \\
\text { Expert opinion }\end{array}$ & III & $\mathrm{Cl}$ \\
\hline
\end{tabular}

With immunohistochemical (IHC) analysis using antibodies against the four MMR proteins, loss of protein expression of the causative gene can be shown.

In 1989, the Amsterdam criteria were proposed in order to provide uniform family material required for international collaborative studies. ${ }^{11}$ In 1999, these criteria were revised and now include various extra-colonic tumours. ${ }^{12}$ In 1997, the Bethesda guidelines were developed to identify individuals with CRC who should be tested for MSI. ${ }^{13}{ }^{14}$ These guidelines were revised in 2004. ${ }^{15}$ Box 1 shows the revised Amsterdam criteria and Bethesda guidelines. After the discovery of mutations in the MMR genes, 14 years ago, the syndrome finally received the attention in the medical community that it deserved. This has led to the identification of large numbers of affected families.

\section{TERMINOLOGY}

Various names for Lynch syndrome have been used in the past century. A workshop in Amsterdam in 1989 agreed upon the name "HNPCC", because at that time the syndrome was unknown to most doctors. This name clarified that the syndrome described an inherited form of CRC. The appropriateness of the name was discussed again at an international meeting in Bethesda in 2004. Most participants considered the term HNPCC to be inappropriate, since the syndrome is also associated with many other tumours. It was proposed that the name "Lynch syndrome" should be reintroduced, and that this name should be reserved for families with strong evidence of MMR deficiency - for example, by the presence of an MMR defect or by the presence of MSI in tumours. ${ }^{15}$ The European group agreed that this name is the best available name for the syndrome. The group suggests that families that meet the original Amsterdam criteria but do not have evidence for MMR deficiency are referred to as having familial CRC.

\section{IDENTIFICATION}

Identification of family members carrying an MMR gene defect is important, as colonoscopic surveillance may be restricted to these individuals, whereas those without a gene defect may be reassured and spared intensified surveillance. Mutation analysis is rather expensive, as four genes may have to be analysed.

Table 2 Lifetime risk of cancer reported in families with an identified mismatch repair mutation

\begin{tabular}{lr}
\hline Colorectal cancer (men) & $28-75 \%$ \\
Colorectal cancer (women) & $24-52 \%$ \\
Endometrial cancer & $27-71 \%$ \\
Ovarian cancer & $3-13 \%$ \\
Gastric cancer & $2-13 \%$ \\
Urinary tract cancer & $1-12 \%$ \\
Brain tumour & $1-4 \%$ \\
Bile duct/gallbladder cancer & $2 \%$ \\
Small-bowel cancer & $4-7 \%$ \\
\hline
\end{tabular}

Moreover, comprehensive screening of these genes is required, as their mutational spectra are wide.

Currently, the Amsterdam II/Revised Bethesda criteria are used to select patients with CRC for molecular genetic and/or IHC analysis of the tumour, and those with evidence of MSI or loss of MMR expression are offered mutation analysis.

Question: are the Amsterdam II criteria and the revised Bethesda guidelines appropriate to select families for molecular genetic analysis of tumours?

One way to establish whether these criteria are appropriate is to determine the proportion of cases with inherited MMR gene mutations that they would miss in a series of unselected patients with CRC. We found six studies in which either MSI or IHC analysis or both tests were performed as the primary screening tool in prospective and unselected series of patients with CRC (table 3). ${ }^{16-21}$

Previous studies have shown that the yield of mutation analysis (positive predictive value) in families that meet the Amsterdam criteria is approximately $50 \%$, and that the yield in families that meet the Bethesda criteria is between $10 \%$ and $20 \%{ }^{22}$ The six studies showed that the sensitivity of the Amsterdam criteria for the detection of mutations was $40 \%$ and that the sensitivity of the Bethesda guidelines was about $90 \%$ (table 3). This means that if the revised Bethesda guidelines had been used, about $10 \%$ of the mutation carriers would have been missed, mostly patients with CRC diagnosed between age 50 and 60 years. According to the revised Bethesda guidelines, in patients with CRC diagnosed in their 50s, special attention should be given to the presence of pathological features that suggest Lynch syndrome (eg, the presence of tumour-infiltrating lymphocytes). If these features are found, the tumours should be tested for MSI. Unfortunately, the studies summarised in table 3 did not present data on the pathological examination of the cancers in these cases.

In view of the high costs of testing all CRCs for MSI or loss of MMR protein, the group believed that the revised Bethesda guidelines are an appropriate tool to help in selecting patients for genetic testing. An alternative approach is to use computer models that are currently being evaluated. ${ }^{23} 24$

Because of the accumulating evidence that MSI is a predictive factor for response to 5-fluorouracil (FU)-based chemotherapy, the group expects that these tests will be performed in an increasing number (if not all) of patients with CRC in the near future.

Conclusion: the revised Bethesda guidelines are appropriate tools to help in selecting families for molecular genetic and/or IHC analysis of tumours (category of evidence II)

Question: which test, MSI or IHC, has the best sensitivity for the detection of MMR gene mutations?

In the literature, many studies have been published on the results of MSI or IHC analysis for the identification of MMRgene mutations. However, most studies were retrospective and the methods that were used varied widely. The number of markers for MSI analysis ranged from 1 to $>10$. For IHC analysis, most studies used two antibodies (MLHl, MSH2) 
Box 1 Amsterdam criteria II and revised Bethesda guidelines

\section{Amsterdam criteria II}

There should be at least three relatives with colorectal cancer (CRC) or with a Lynch syndrome-associated cancer: cancer of the endometrium, small bowel, ureter or renal pelvis.

- one relative should be a first-degree relative of the other two,

- at least two successive generations should be affected,

- at least one tumour should be diagnosed before the age of 50 years,

- FAP should be excluded in the CRC case if any,

- tumours should be verified by histopathological examination.

\section{Revised Bethesda guidelines}

1. CRC diagnosed in a patient aged $<50$ years.

2. Presence of synchronous, metachronous colorectal or other Lynch syndrome-related tumours, ${ }^{*}$ regardless of age.

3. CRC with MSI-H phenotype diagnosed in a patient aged $<60$ years.

4. Patient with CRC and a first-degree relative with a Lynch syndrome-related tumour, with one of the cancers diagnosed at age $<50$ years.

5. Patient with CRC with two or more first-degree or seconddegree relatives with a Lynch syndrome-related tumour, regardless of age.

*Lynch syndrome-related tumours include colorectal, endometrial, stomach, ovarian, pancreas, ureter, renal pelvis, biliary tract and brain tumours, sebaceous gland adenomas and keratoacanthomas, and carcinoma of the small bowel.

against the MMR proteins; other studies used three or four antibodies (MLH1, MSH2, MSH6, PMS2). In the studies in which both MSI analysis and IHC analysis have been used prospectively (table 4), the sensitivity of MSI analysis was slightly better than that of IHC analysis. ${ }^{17}$ 19-21 24-28 The false negatives with IHC might be due to the fact that the antibody detects a fragment of the truncated protein. There is one large (German) study that evaluated the outcome of these tests prospectively in families that meet the Amsterdam, Bethesda or slightly modified criteria. In this study, MSI analysis (using the
Bethesda set of five markers) and IHC analysis (two antibodies) were performed in 1119 index patients. ${ }^{26}$ Altogether, 230 pathogenic MMR gene mutations were identified. The sensitivity of MSI analysis was $100 \%$ and that of IHC analysis was 94\%. A Dutch study showed that by adding antibodies against PMS2 the sensitivity for the detection of MLH1 mutations increased. ${ }^{29}$ Had the German investigators used all four antibodies, the sensitivity of IHC might have been higher.

The advantage of IHC is that it may direct mutation analysis because the pattern of staining is suggestive of the underlying gene defect. This is the reason for most authors recommending the use of IHC as the first step in families with a high probability of carrying a mutation (eg, families that meet the Amsterdam criteria or families with a high predicted probability based on calculations using computer models (fig 1). ${ }^{22-2426}$ Because of the incomplete sensitivity of IHC analysis, MSI is recommended for cases with a high prior probability of Lynch syndrome but with apparently normal expression of the MMR proteins. In families with a moderately increased probability of carrying a mutation, depending on the experience of the centre, either MSI or IHC analysis might be used as the first step to exclude the presence of MMR deficiency. Preferably, colon tumour tissue is used for MSI/IHC analysis. However, if colon tumour tissue is not available, other tumours-for example, endometrial cancer or adenomatous polyp-may be analysed. Unfortunately, the few studies that are available showed that the sensitivity of MSI/IHC for MMR mutations in these tumour tissues was lower than that of the same analysis of colon cancers. $^{31}{ }^{32}$

Because interpretation of the pedigree information, the pathology of the tumour and the outcome of MSI and IHC testing can be complex, our group advises that these data be discussed together by a multidisciplinary team.

Conclusion: the sensitivity of MSI analysis is slightly higher than that of IHC analysis (category of evidence II). In families with a high probability of having a mutation (Amsterdam II criteria, computer models), IHC is the best first step because it may direct mutation analysis. In other families, either MSI or IHC analysis might be used as the first step. The results of pedigree analysis and MSI/IHC analysis should be discussed in a multidisciplinary setting (pathologist, clinical/molecular geneticist, gastroenterologist, surgeon, etc; grade $\mathrm{C}$ ).

\section{SURVEILLANCE OF THE COLORECTUM}

Studies have shown that the adenoma-carcinoma sequence may also be applied in the development of CRC in families with Lynch syndrome. Since the 1980s, colonoscopic surveillance has

Table 3 Outcome of mismatch repair gene mutation analysis in relation to clinical criteria and results of microsatellite instability and immunohistochemical analysis in a population-based or consecutive series of unselected colorectal cancer

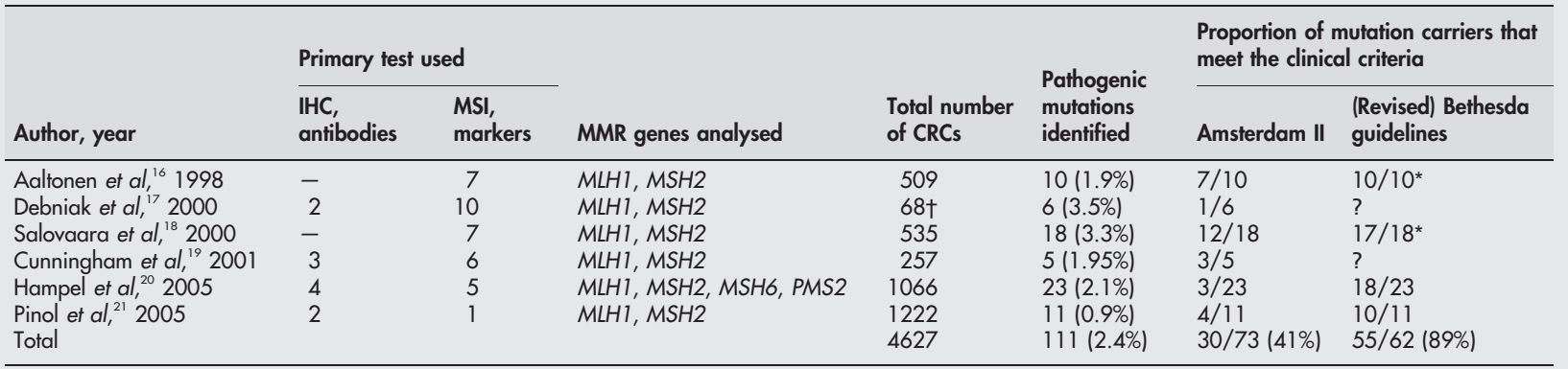

-, not performed; ?, not evaluated; CRC, colorectal cancer; IHC, immunohistochemical; MMR, mismatch repair; MSI, microsatellite instability.

†The original number of consecutive CRCs was 168 , including 143 sporadic cases and 25 suspected cases. In total, 43 sporadic cases and 25 suspected cases were analysed.

${ }^{*}$ Communicated with authors. 


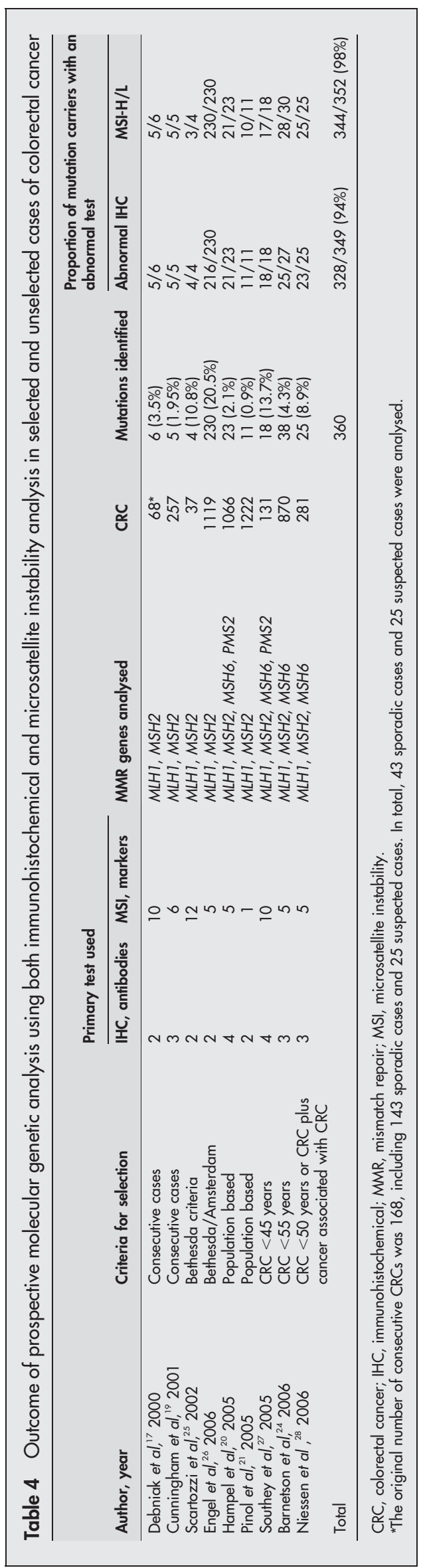

been recommended for these families. The following question is relevant.

Question: does colonoscopic surveillance of the colorectum lead to early detection of CRC or adenoma and reduction of CRC-related mortality?

A literature search showed that nine studies have addressed at least the first part of the question. ${ }^{33-41}$ Table 5 summarises the nature of these studies, the number of families involved and the categories of evidence produced. All the studies showed that surveillance led to the detection of CRC at an earlier stage compared with the stage in historical controls. The only prospective controlled trial showed that surveillance led to a $63 \%$ reduction of $\mathrm{CRC}^{38}$ Two studies assessed the effect of surveillance on CRC-associated mortality. A Finnish study showed that colonoscopic surveillance significantly decreased the mortality associated with CRC. ${ }^{38}$ A study from the Netherlands evaluated the relative mortality in a large series of families over a period of 45 years. In the Netherlands, a national registry of families with Lynch syndrome was established in 1985 to promote the identification of such families and to encourage participation in surveillance programmes. ${ }^{35}$ Mortality in these families has decreased significantly in the last 15 years.

Conclusion: periodic examination by colonoscopy leads to the detection of CRC at an earlier stage, to a $63 \%$ reduction of the risk of CRC and to a significant reduction of the mortality associated with CRC (category of evidence IIb).

The protocols that have been used in studies of surveillance have varied with respect to the surveillance intervals. Some studies advised a 3-yearly colonoscopy and others colonoscopy every year.

Question: what is the optimal surveillance protocol for Lynch syndrome in terms of surveillance interval?

A search of the literature did not reveal any studies that compared different surveillance intervals. The Finnish trial showed that 3-yearly colonoscopy significantly reduced the incidence of CRC and CRC-related mortality. ${ }^{38}$ Therefore, the only evidence available suggests that a 3-yearly interval may be adequate. However, several observational studies suggest that (interval) cancers can occur within a 3-year interval after colonoscopy. In a Finnish study on surveillance of 56 families, the stage distribution of CRC was significantly more favourable in patients $(\mathrm{n}=35)$ with cancer detected by surveillance than in patients $(\mathrm{n}=115)$ with symptomatic presentation of CRC. ${ }^{39}$ However, a total of 21 cancers were diagnosed after a previous "clean" colonoscopy, and half of them were diagnosed within (or at) an interval of 3 years. These included two Dukes C cancers diagnosed 15 and 20 months after the previous examination. In a Dutch long-term follow-up study, a number of interval cancers were also observed. Advanced cancers (Dukes C) were only observed at intervals of $>2$ years, whereas all Dukes A and B tumours were detected within an interval of $<2$ years. These observations, together with the finding that adenomas observed in HNPCC more often show high-grade dysplasia and villosity, suggest that the adenoma-carcinoma sequence is accelerated in Lynch syndrome. ${ }^{32}{ }^{43}$ Therefore, the most appropriate surveillance interval probably lies between 1 and 2 years. In highly selected cases-for example, mutation carriers who have recurrent adenomas-a prophylactic subtotal colectomy may be discussed as an option.

Conclusion: a 3-year interval is proven to be (at least partly) effective (category of evidence IIb); in view of the observation of advanced CRC detected 2-3 years after colonoscopy, the optimal interval probably lies between 1 and 2 years (category of evidence III, grade C).

Question: at what age should surveillance be started and at which age might surveillance be discontinued? 


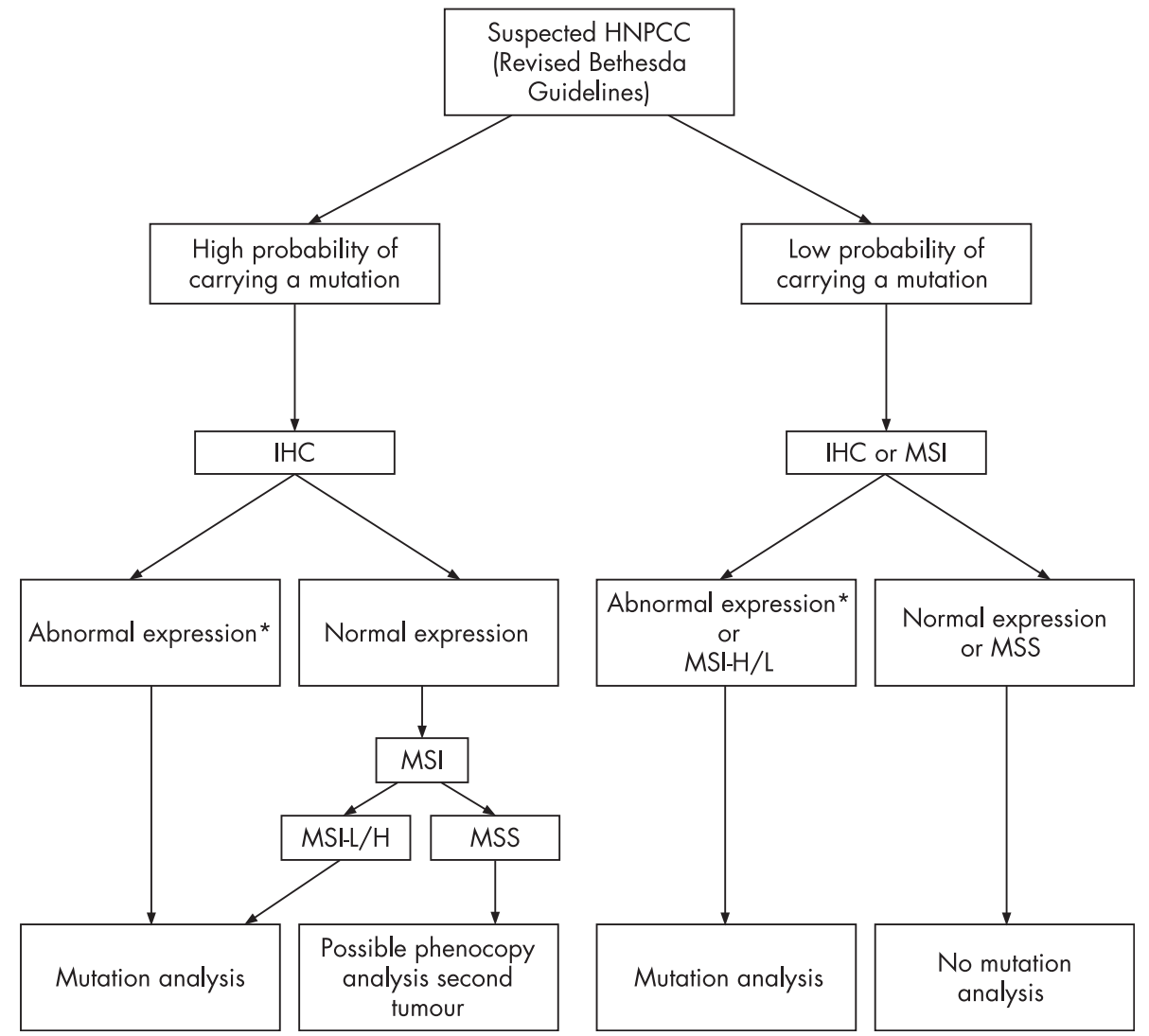

Figure 1 Strategy for identification of patients with colorectal cancer with a mismatch repair gene defect. *If $M L H I$ expression is lost, DNA analysis of BRAF in the tumour can be performed because the presence of a BRAF-V600E mutation makes hereditary non-polyposis colorectal cancer (HNPCC) very unlikely. IHS, immunohistochemical; MSI, microsatellite instability; MSS, microsatellite stability. ${ }^{30}$

Many studies have shown that the risk of developing CRC before the age of 25 years is very low. ${ }^{7-10}$ In a series of 246 CRC from families with Lynch syndrome known at the Dutch HNPCC Registry, only $2(0.8 \%)$ patients developed CRC before the age of 20 years and another two between age 20 and 25 years. $^{44}$ Based on these data, the group advises to start surveillance between age 20 and 25 years. In the literature, recommendations regarding the upper age limit of surveillance are very sparse. One study has reported that the risk of mutation carriers aged 70-75 years developing CRC in the next 10 years is significant ${ }^{44}$ However, at the age of 80 years, they found that the risk of developing CRC in the next 10 years relative to their life expectancy was low. Based on these findings, the authors recommended continuing surveillance up to the age of 80 years in mutation carriers if they were in good health. However, the European group advises that decisions on

Table 5 Studies on surveillance of families with Lynch syndrome

\begin{tabular}{|c|c|c|}
\hline Author, year & $\begin{array}{l}\text { Number of } \\
\text { families }\end{array}$ & $\begin{array}{l}\text { Type of study/category } \\
\text { of evidence }\end{array}$ \\
\hline Love et al, ${ }^{33} 1984$ & 4 & Descriptive/III \\
\hline Mecklin et al, 1987 & 22 & Descriptive/III \\
\hline Vasen et al, 1989 & 22 & Descriptive/III \\
\hline Vasen et al, 1995 & 50 & Descriptive/III \\
\hline Jarvinen et al, ${ }^{37}{ }^{38} 1995 / 2000$ & 22 & $\begin{array}{l}\text { Non-randomised } \\
\text { controlled trial/Ilb }\end{array}$ \\
\hline Renkonen et al, 2000 & 57 & Descriptive/III \\
\hline Arrigoni et al ${ }^{40} 2005$ & 22 & Descriptive/III \\
\hline $\begin{array}{l}\text { De Vos tot Nederveen Cappel } \\
\text { et al }{ }^{41} 2002\end{array}$ & 114 & Descriptive/III \\
\hline
\end{tabular}

the upper age limit of surveillance should be made on an individual basis. For example, in a 75-year-old mutation carrier with severe cardiovascular disease, surveillance can be discontinued. On the other hand, in an 80-year-old mutation carrier who is still in good health, especially if there is a personal history of adenomas and colon cancer, it is reasonable to continue surveillance.

Conclusion: surveillance should start between age 20 and 25 years. Decisions on the upper age limit of surveillance depend on the patient's general state of health and should be made on an individual basis (category of evidence III, grade C).

Question: which surveillance protocol should be recommended in families with clustering of CRC without evidence of MSI in the tumours?

In a significant proportion (approximately 30\%) of families that meet the Amsterdam criteria, the results of the MSI and IHC analysis of the colorectal tumour(s) are negative. ${ }^{45}$ Clustering of CRC by chance or genetic defects other than those of MMR may be responsible for the disease in such families, and they do not have Lynch syndrome. These families are characterised by a more advanced age of onset of CRC than in families with Lynch syndrome, and the absence of endometrial cancer and multiple tumours. A recent study reported that the risk of developing CRC in such families is increased only by a factor of 2.3. ${ }^{45}$ Another study compared the results of surveillance in families with clustering of CRC with and without MSI. ${ }^{46}$ The results showed that the yield of adenomas was the same in both types of families. However, CRC was identified only in the families with MSI tumours. In families without evidence for MMR deficiency, a less intensive colonoscopic surveillance programme (eg, colonoscopy: $1 \times / 3-$ 5 years, starting 5-10 years before the first diagnosis of CRC or at $>45$ years) might be appropriate. In view of the absence of 
endometrial cancer in such families, surveillance of the endometrium is not indicated.

Conclusion: in families with clustering of CRC but without evidence of MMR deficiency (families without Lynch syndrome), a less intensive surveillance protocol is recommended-that is, colonoscopy at 3-5 year intervals, starting 5-10 years before the first diagnosis of CRC or at $>45$ years (category of evidence III, grade C)

\section{SURVEILLANCE OF THE ENDOMETRIUM/OVARY}

Previous studies have shown that carriers of an MMR mutation have a high risk of developing endometrial cancer. ${ }^{7}$ Although it is known that the majority of (sporadic) endometrial cancers are detected at an early stage, about $10-15 \%$ of patients with such tumours will ultimately die from metastatic disease. In view of this significant mortality and the high risk of developing endometrial cancer in families with Lynch syndrome, most authors advise surveillance of the endometrium.

Question: how effective is surveillance for endometrial cancer in families with Lynch syndrome?

British and Dutch investigators evaluated the outcome of surveillance of 269 women from families suspected of having Lynch syndrome..$^{48}$ The surveillance programme consisted of ultrasound every $1-2$ years. It did not lead to the detection of premalignant lesions or endometrial cancer. However, two women presented with symptoms at 6 and 24 months after a normal ultrasound and were diagnosed with endometrial cancer. Both tumours were in an early stage (Figo I). In another study from the Netherlands, 41 women from families with Lynch syndrome underwent surveillance by transvaginal ultrasound (TVU) followed by aspiration biopsy in suspected cases. After a mean follow-up of 5 years, premalignant lesions-that is, complex atypia-were detected in three patients. There was one interval cancer diagnosed 8 months after a normal ultrasound. This tumour was at an early stage. A recent study of 175 subjects from Finland reported the results of surveillance by TVU and aspiration biopsy. ${ }^{49}$ Complex atypia was found in 5 patients, endometrial cancer was found in 11 , and there were 2 interval cancers. Out of the 11 screen-detected cancers, 6 cancers were identified only by aspiration biopsy and not by TVU. Table 6 summarises the outcomes of the studies. American investigators reported on a retrospective cohort of 315 women, all mutation carriers, 61 of whom had prophylactic surgery and were then followed up for approximately 10 years. No endometrial cancer or ovarian cancer developed in those women who had prophylactic surgery, whereas 33\% of women who did not have surgery developed endometrial cancer and $5.5 \%$ developed ovarian cancer. ${ }^{50}$

In conclusion, two of the three available studies suggested that surveillance may lead to the detection of premalignant lesions, and one study suggested that it may also lead to the detection of endometrial cancer at an early stage. More prospective studies are needed to establish the most appropriate screening protocol. Because of the higher risk of developing endometrial cancer in carriers of an MSH6 mutation, hysterectomy may be suggested to these women after menopause. This surgery may also be considered for carriers of mutations in the other MMR genes, and for women who require surgery for a CRC. In view of the risk of ovarian cancer and the failure of early detection of such tumours by TVU and CA-125 estimation, bilateral salpingo-oophorectomy might be considered in mutation carriers after completion of family planning.

Conclusion: the value of surveillance for endometrial cancer is unknown. Surveillance by gynaecological examination, TVU and aspiration biopsy starting from age 30-35 years may lead to the detection of premalignant lesions and early cancers (category of evidence III, grade C). Prophylactic hysterectomy and salpingo-oophorectomy may be an option for women with Lynch syndrome, since it substantially reduces site-specific cancers (grade C).

\section{SURVEILLANCE FOR OTHER RELATED CANCERS}

Other cancers associated with Lynch syndrome include cancer of the stomach, ureter, renal pelvis, small bowel, bile ducts and tumours of the brain. The lifetime risk of developing one of these cancers is relatively low $(<10 \%)$, and may be associated with the underlying MMR defect. The risk of developing gastric cancer may be higher in some countries. The International Society of Gastrointestinal Hereditary Tumours recommends surveillance for cancer of the stomach if the cancer clusters in the family (more than one case). ${ }^{51}$ However, the European group is of the opinion that surveillance in families with Lynch syndrome for gastric cancer may also be considered in countries with a high incidence of such tumours.

In the decision-making process regarding which surveillance protocol should be recommended, a reasonable approach might be first to discuss all the various cancer risks with the patient, then discuss which screening protocols are established as effective based on published evidence-for example, colon and possibly endometrium screening (see above). Finally, the doctor and patient should weigh up the possible benefits versus costs and risks for screening for other cancers. In addition, it should be recommended to all at-risk family members that they should contact a doctor early if they are worried about specific signs or symptoms.

Table 7 summarises the guidelines for surveillance of families with Lynch syndrome recommended by the collaborative group of the European experts in hereditary gastrointestinal cancer. This protocol is indicated in families with an identified MMR defect, and also in families with clustering of CRC and other related cancers with evidence of MMR deficiency-for example, by the presence of MSI or loss of expression in tumours (with the exception of families of patients with such features caused by hypermethylation of $M L H 1$ ).

\section{SURGICAL MANAGEMENT OF COLORECTAL CANCER}

Several studies have shown that patients with Lynch syndrome have an increased risk of developing multiple (synchronous and metachronous) CRCs. Thus, before resection of a colon tumour, it is important to visualise the complete colon, because of the risk of a synchronous tumour.

Question: what is the best surgical treatment for a patient who is diagnosed with CRC associated with Lynch syndrome?

A Dutch study reported that the risk of developing a second colon tumour after treatment of a primary CRC in Lynch syndrome was $16 \%$ after 10 years of follow-up. ${ }^{41}$ In view of this substantial risk, the question arises whether a subtotal colectomy instead of a segmental resection might be the preferred treatment in patients from families with Lynch syndrome with a primary tumour. In a recent study, a decision analysis was performed to compare the life expectancy for patients undergoing subtotal colectomy or partial resection for a primary screen-detected CRC. ${ }^{52}$ The results indicated that subtotal colectomy performed at a young age ( $\leqslant 47$ years) would lead to an increased life expectancy of up to 2.3 years. Unfortunately, the authors were not able to use quality of life (QoL)-adjusted life expectance, because studies on QoL that specifically consider patients with Lynch syndrome were not available in the literature. Although for sporadic CRC QoL after segmental resection has been reported to be better than that after subtotal colectomy, in families with Lynch syndrome, QoL after segmental resection may be decreased by the need for colonoscopy (vs sigmoidoscopy after subtotal colectomy) and the fear of a second tumour. 
Table 6 The outcome of surveillance for endometrial cancer in families with Lynch syndrome

\begin{tabular}{|c|c|c|c|}
\hline & $\begin{array}{l}\text { UK/The Netherlands } \\
\text { (Dove-Edwin et al, }{ }^{47} \text { 2002) }\end{array}$ & $\begin{array}{l}\text { The Netherlands } \\
\text { (Rijcken et al, }{ }^{48} \text { 2003) }\end{array}$ & $\begin{array}{l}\text { Finland } \\
\text { (Renkonen-Sinisalo et al, } \\
\text { 2006) }\end{array}$ \\
\hline Number of subjects & 269 & 41 & 175 \\
\hline Mutation carriers & Not mentioned & $27 \%$ & $100 \%$ \\
\hline Protocol & TVU & TVU & TVU and aspiration biopsy \\
\hline $\begin{array}{l}\text { Patient years of } \\
\text { follow-up }\end{array}$ & 826 & 197 & 759 \\
\hline Number of scans & 522 & 179 & 476 \\
\hline Surveillance interval & $1-2$ years & 1 year & $2-3$ years \\
\hline Premalignant lesions & - & 3 complex atypia & 5 complex atypia \\
\hline Screen-detected cancer & - & - & $12^{*}$ \\
\hline Interval cancer & 2 & 1 & 2 \\
\hline Figo I & 2 & 1 & 12 \\
\hline Figo II & & & 1 \\
\hline Figo III & & & 1 \\
\hline
\end{tabular}

Based on these findings and the substantial risk of developing a second tumour, subtotal colectomy with ileorectal anastomosis can be considered if colon cancer is detected in a young patient participating in a surveillance programme. A prospective study that also addresses QoL should evaluate which surgical option is the most appropriate in Lynch syndrome. Until the outcome of such studies is available, the Mallorca group recommends discussing the pros and cons of both options with a patient from a family with Lynch syndrome who develops CRC.

Conclusion: regarding the treatment of CRC in patients from families with Lynch syndrome, no controlled trials are available; one decision analysis study has reported an increase in life expectancy with subtotal colectomy compared with partial resection; in view of this study and the high risk of a second CRC, the option of extensive resection should be discussed in young patients (eg, <50 years; category of evidence III, grade C).

\section{CHEMOTHERAPY}

Currently, at least three chemotherapeutic agents have been proven to be effective in the treatment of CRC - that is, 5-FU with or without leucovorin, oxaliplatin and irinotecan (CPT11). Unfortunately, the effectiveness of these agents in patients with MSI-H or Lynch syndrome tumours is unknown. In vitro studies have suggested that MMR-deficient colon cancer cells might not respond to 5-FU-based chemotherapy. ${ }^{53}$ On the other hand, CRC cell lines defective in MMR exhibit increased sensitivity to CPT11.$^{54}$
Question: is chemotherapy effective in patients with MSI-H tumours?

The effect of chemotherapy in patients with MSI-H or HNPCC tumours has been reported in only a few studies (table 8). ${ }^{55-59}$ Most studies showed that there was no benefit of 5 -FU treatment in such patients. One small study on stage IV CRC patients reported complete or partial responses to treatment with irinotecan in 4 of 7 patients with MSI-H tumours, compared with 7 of 65 patients with MSI-L/MSS tumours. ${ }^{59}$

Because most studies are retrospective, all authors urge caution in implementing these findings in clinical practice until they are confirmed by prospective studies. Because it may be unethical to withhold chemotherapy in a clinical trial for potentially curable advanced-stage colon cancer, the best format of such studies is to compare effective drugs such as CPT11 or oxalaplatin with 5-FU.

Conclusion: experimental and clinical studies suggest that MSI-H tumours are resistant to 5-FU-based chemotherapy; however, prospective clinical trials are needed before definitive recommendations can be given (category of evidence III).

\section{DISCUSSION}

The guidelines for the management of Lynch syndrome provided in this manuscript are the result of intensive discussions among the participants of a 2-day workshop held in Mallorca in April 2006. Because most of the studies that form the basis for the recommendations were descriptive and/or retrospective in nature, many of these recommendations were

Table 7 Surveillance protocol in Lynch syndrome and familial clustering of colorectal cancer

\begin{tabular}{|c|c|c|c|}
\hline Disorder & Lower age limit (years) & Examination & Interval (years) \\
\hline \multirow[t]{4}{*}{ Lynch syndrome } & $20-25$ & Colonoscopy & $1-2$ \\
\hline & $30-35$ & $\begin{array}{l}\text { Gynaecological examination, } \\
\text { transvaginal ultrasound, } \\
\text { aspiration biopsy }\end{array}$ & $1-2$ \\
\hline & $30-35$ & Gastroduodenoscopy* & $1-2$ \\
\hline & $30-35$ & $\begin{array}{l}\text { Abdominal ultrasound, } \\
\text { urinalysis and cytology urinet }\end{array}$ & $1-2$ \\
\hline $\begin{array}{l}\text { Familial clustering of } \\
\text { colorectal cancer without } \\
\text { evidence of MSI }\end{array}$ & $\begin{array}{l}45-50 \text { or } 5-10 \text { before age } \\
\text { at diagnosis of first CRC in family }\end{array}$ & Colonoscopy & $3-5$ \\
\hline
\end{tabular}

CRC, colorectal cancer; MSI, microsatellite instability.

*If gastric cancer runs in the family or in countries with a high incidence of gastric cancer

tIf urinary tract cancer runs in the family.

$\ddagger$ Amsterdam positive families. 
Table 8 Studies on the effectiveness of chemotherapy in patients with MSI-H tumours

\begin{tabular}{|c|c|c|c|c|}
\hline Author, year & Type of study and selection criteria & Agents & $\begin{array}{l}\text { Patients with } \\
\text { MSI-H tumour }\end{array}$ & Effect of chemotherapy \\
\hline Liang et $a l_{,}^{55} 2002$ & Prospective, non-randomised; stage IV CRC & $\begin{array}{l}\text { High-dose 5-FU/ } \\
\text { leucovorin }\end{array}$ & 52 & $\begin{array}{l}\text { Better survival in patients with MSI-H } \\
\text { tumours who received chemotherapy }\end{array}$ \\
\hline Ribic et al, 2003 & $\begin{array}{l}\text { Retrospective MSI analysis of tumours from patients } \\
\text { who participated in a multicentre RCT } 20-25 \text { years ago; } \\
\text { CRC stage II/III }\end{array}$ & $\begin{array}{l}5 \text {-FU/leucovorin or } \\
\text { levamisol }\end{array}$ & 95 & No survival differences \\
\hline Carethers et al, ${ }^{57} 2004$ & Retrospective, consecutive patients; CRC stage II/III & 5-FU-based & 36 & No survival differences \\
\hline De Vos et al ${ }_{1}^{58} 2004$ & $\begin{array}{l}\text { Retrospective, CRC stage III patients from families } \\
\text { with HNPCC }\end{array}$ & $\begin{array}{l}\text { 5-FU/leucovorin or } \\
\text { levamisol }\end{array}$ & 92 & No survival differences \\
\hline Fallik et al, ${ }^{59} 2003$ & Non-randomised controlled trial; CRC stage IV & Irinotecan (CPT11) & 7 & 3 partial and 1 complete response \\
\hline
\end{tabular}

based on expert opinion, and we were fortunate to convene an extensive expert panel. During the workshop, it became clear that there are still many aspects of Lynch syndrome about which new knowledge needs to be gained through further research.

Regarding the identification of Lynch syndrome, the available criteria (revised Bethesda guidelines) seemed to be effective for the selection of families for analysis of tumour MMR status. However, even with the use of these guidelines, a significant proportion of mutation carriers may be missed. The sensitivity of the Bethesda criteria might be improved by investigating these missed cases. For example, since most missed mutation carriers are diagnosed with CRC between age 50 and 60 years, it may be appropriate to increase the age at diagnosis below which MSI analysis is recommended. Another possibility might be to evaluate all CRCs, for example by IHC. Because there is increasing evidence that MSI/IHC is an important prognostic factor and may predict the response to chemotherapy, these tests might in future be performed on a much larger scale, if not in all CRC cases.

Studies have shown that colorectal surveillance in Lynch syndrome leads to a reduction of CRC and associated mortality. However, a substantial proportion (estimated at $5-10 \%$ per 10 years of follow-up) of patients develop (interval) cancers under surveillance. For this reason, future research should address how new screening tools such as chromoendoscopy, high-resolution colonoscopy with narrow banding or DNA analysis of the faeces might help in the early detection of colorectal tumours. ${ }^{60}$

Very few data are available on the effectiveness of surveillance for endometrial cancer. A prospective trial in which TVU is being compared with TVU and aspiration biopsy should be undertaken.

For patients with Lynch syndrome who present with CRC, the surgical choice lies between partial resection and more extensive surgery such as subtotal colectomy and ileorectal anastomosis. In view of the increased risk of developing a second tumour and also the evidence for improved life expectancy after extensive surgery, the best option seems to be a subtotal colectomy. However, because such an extensive surgical procedure might have significant impact on the QoL, a randomised controlled trial should be performed, which includes assessment of the QoL and functional outcome after the two procedures.

The use of chemotherapy in patients with Lynch syndrome having CRC, or in patients with MSI-H tumours, is controversial. Because of the effective surveillance programmes, few patients with metastatic disease are currently being identified. Therefore, future trials on the effect of various chemotherapeutic regimens in Lynch syndrome or in patients with MSI-high tumours should be conducted on a European level or even worldwide.
There is ample evidence that the expression of Lynch syndrome is influenced by environmental factors. However, studies that indicate which environmental factors play a significant role are rare. Since 1998, the effect of resistant starch and aspirin has been investigated in a large randomised placebo-controlled trial with families having Lynch syndrome from all over the world (http://www.CAPPs.com). The results will be published in 2007. A new trial (the Prevention of Endometrial Tumours trial) is being developed to explore the possibility of chemoprevention using the progesterone-releasing Mirena intrauterine device.

In conclusion, the guidelines described in this manuscript may be helpful for the appropriate management of families with Lynch syndrome. There is an urgent need for prospective controlled studies to improve the care of these families further.

The workshop in Mallorca identified several collaborative studies the group will focus on to clarify some of the controversial issues that exist in the clinical management of Lynch syndrome.

\section{Authors' affiliations}

H F A Vasen*, Department of Gastroenterology, Leiden University Medical Centre, Leiden, The Netherlands

G Möslein*, Department of Surgery, St Josefs Hospital Bochum-Linden (Helios), Bochum, Germany

A Alonso, Department of Medical Genetics, Hospital Virgen del Camino, Pamplona, Spain

I Bernstein, Department of Gastroenterology, Hvidrove Hospital, Hvidrove, Denmark

L Bertario, Department of Surgery, Hospital Tumori, Milan, Italy I Blanco, Department of Genetic Counselling, Prevention and Cancer, Catelonian Institute of Oncology, Barcelona, Spain

J Burn, Institute of Human Genetics, Newcastle upon Tyne, UK

G Capella, Translational Research Laboratory IDIBELL, Institut Catala D'Oncologia, Barcelona, Spain

C Engel, Institute of Medical Informatics, Statistics and Epidemiology, University of Leipzig, Leipzig, Germany

I Frayling, J R Sampson, Institute of Medical Genetics, Cardiff, UK W Friedl, Institute of Human Genetics, University Clinics, Bonn, Germany F J Hes, J Wiinen, Department of Clinical Genetics, Leiden University Medical Centre, Leiden, The Netherlands

S Hodgson, Department of Clinical Genetics, St George's Hospital, London, UK

J-P Mecklin, Department of Surgery, Jyvaskyla Central Hospital, Jyvaskyla, Finland

P Møller, Department of Genetics, Norwegian Radium Hospital, Oslo,

Norway

F Nagengast, Department of Gastroenterology, University Medical Centre, Radboud, Niimegen, The Netherlands

Y Parc, Department of Digestive Surgery, Hospital Saint-Antoine, University Pierre et Marie, Paris, France

L Renkonen-Sinisalo, Department of Surgery, Helsinki University Central Hospital, Helsinki, Finland 
A Stormorken, Department of Medical Genetics, Ullevål University Hospital, Oslo, Norway

*HFAV and GM contributed equally to the preparation of this manuscript. Competing interests: None declared.

\section{REFERENCES}

Lynch HT, Chapelle de la A. Hereditary colorectal cancer. N Engl J Med 2003;348:919-32.

2 Al Tassan N, Chmiel NH, Maynard J, Fleming N, Livingston AL, Williams GT, Hodges AK, Davies DR, David SS, Sampson JR, Cheadle JP. Inherited variants of MYH associated with somatic $\mathrm{G}: \mathrm{C} \rightarrow \mathrm{T}: \mathrm{A}$ mutations in colorectal tumors. Nat Genet 2002;30:227-32.

3 Vasen HF, Wijnen JT, Menko FH, Kleibeuker JH, Taal BG, Griffioen G, Nagengast FM, Meijers-Heiiboer EH, Bertario L, Varesco L, Bisgaard ML, Mohr J, Fodde R, Khan PM. Cancer risk in families with hereditary nonpolyposis colorectal cancer diagnosed by mutation analysis. Gastroenterology 1996; 110:1020-7.

4 Dunlop MG, Farrington SM, Carothers AD, Wyllie AH, Sharp L, Burn J, Liu B, Kinzler KW, Vogelstein B. Cancer risk associated with germline DNA mismatch repair gene mutations. Hum Mol Genet 1997;6:105-10

5 Aarnio M, Sankila R, Pukkala E, Salovaara R, Aaltonen LA, de la Chapelle A, Peltomaki $P$, Mecklin JP, Jarvinen HJ. Cancer risk in mutation carriers of DNA mismatch-repair genes. Int J Cancer 1999;81:214-18.

6 Vasen HF, Stormorken A, Menko FH, Nagengast FM, Kleibeuker JH, Griffioen G, Taal BG, Moller P, Wijnen JT. MSH2 mutation carriers are at higher risk of cancer than $\mathrm{MLHI}$ mutation carriers: a study of hereditary nonpolyposis colorectal cancer families. J Clin Oncol 2001;19:4074-80.

7 Hendriks YM, Wagner A, Morreau H, Menko F, Stormorken A, Quehenberger F, Sandkuijl L, Moller P, Genuardi M, Van Houwelingen $H$, Tops $C$, van Puijenbroek M, Verkuijlen P, Kenter G, Van Mil A, Meijers-Heijboer H, Tan GB, Breuning $\mathrm{MH}$, Fodde R, Wijnen JT, Brocker-Vriends AH, Vasen $\mathrm{H}$. Cancer risk in hereditary nonpolyposis colorectal cancer due to MSH6 mutations: impact on counseling and surveillance. Gastroenterology 2004; 127:17-25.

8 Quehenberger F, Vasen HF, van Houwelingen HC. Risk of colorectal and endometrial cancer for carriers of mutations of the hMLH1 and hMSH2 gene: correction for ascertainment. J Med Genet 2005;42:491-6.

9 Hampel H, Stephens JA, Pukkala E, Sankila R, Aaltonen LA, Mecklin JP, de la Chapelle A. Cancer risk in hereditary nonpolyposis colorectal cancer syndrome: later age of onset. Gastroenterology 2005;129:415-21.

10 Jenkins MA, Baglietto L, Dowty JG, Van Vliet CM, Smith L, Mead L, Macrae FA, St John DJ, Jass JR, Giles GG, Hopper JL, Southey MC. Cancer risks for mismatch repair gene mutation carriers: a population-based early onset case-family study. Clin Gastroenterol Hepatol 2006:4:489-98.

11 Vasen HF, Mecklin JP, Khan PM, Lynch HT. The International Collaborative Group on Hereditary Non-Polyposis Colorectal Cancer (ICG-HNPCC). Dis Colon Rectum 1991;34:424-5.

12 Vasen HF, Watson P, Mecklin JP, Lynch HT. New clinical criteria for hereditary nonpolyposis colorectal cancer (HNPCC, Lynch syndrome) proposed by the International Collaborative group on HNPCC. Gastroenterology 1999;116:1453-6.

13 Rodriguez-Bigas MA, Boland CR, Hamilton SR, Henson DE, Jass JR, Khan PM, Lynch H, Perucho M, Smyrk T, Sobin L, Srivastava S. A National Cancer Institute Workshop on Hereditary Nonpolyposis Colorectal Cancer Syndrome: meeting highlights and Bethesda guidelines. J Natl Cancer Inst 1997;89:1758-62.

14 Boland CR, Thibodeau SN, Hamilton SR, Sidransky D, Eshleman JR, Burt RW, Meltzer SJ, Rodriguez-Bigas MA, Fodde R, Ranzani GN, Srivastava S. A National Cancer Institute Workshop on Microsatellite Instability for cancer detection and familial predisposition: development of international criteria for the determination of microsatellite instability in colorectal cancer. Cancer Res 1998:58:5248-57.

15 Umar A, Boland CR, Terdiman JP, Syngal S, de la CA, Ruschoff J, Fishel R, Lindor NM, Burgart $\amalg$, Hamelin R, Hamilton SR, Hiatt RA, Jass J, Lindblom A, Lynch HT, Peltomaki P, Ramsey SD, Rodriguez-Bigas MA, Vasen HF, Hawk ET, Barrett JC, Freedman AN, Srivastava S. Revised Bethesda Guidelines for hereditary nonpolyposis colorectal cancer (Lynch syndrome) and microsatellite instability. J Natl Cancer Inst 2004;96:261-8.

16 Aaltonen LA, Salovaara R, Kristo P, Canzian F, Hemminki A, Peltomaki P, Chadwick RB, Kaariainen $H$, Eskelinen $M$, Jarvinen $H$, Mecklin JP, de la Chapelle A. Incidence of hereditary nonpolyposis colorectal cancer and the feasibility of molecular screening for the disease. N Engl J Med 1998;338: 1481-7.

17 Debniak T, Kurzawski G, Gorski B, Kladny J, Domagala W, Lubinski J. Value of pedigree/clinical data, immunohistochemistry and microsatellite instability analyses in reducing the cost of determining hMLH1 and hMSH2 gene mutations in patients with colorectal cancer. Eur J Cancer 2000;36:49-54

18 Salovaara R, Loukola A, Kristo P, Kaariainen H, Ahtola H, Eskelinen M, Harkonen N, Julkunen R, Kangas E, Ojala S, Tulikoura J, Valkamo E, Jarvinen H, Mecklin JP, Aaltonen LA, de la Chapelle A. Population-based molecular detection of hereditary nonpolyposis colorectal cancer. J Clin Oncol 2000;18:2193-200.

19 Cunningham JM, Kim CY, Christensen ER, Tester DJ, Parc Y, Burgart L Halling KC, McDonnell SK, Schaid DJ, Walsh VC, Kubly V, Nelson H, Michels VV, Thibodeau SN. The frequency of hereditary defective mismatch repair in a prospective series of unselected colorectal carcinomas. Am J Hum Genet 2001;69:780-90.

20 Hampel H, Frankel WL, Martin E, Arnold M, Khanduja K, Kuebler P, Nakagawa H, Sotamaa K, Prior TW, Westman J, Panescu J, Fix D, Lockman J, Comeras I, de la Chapelle A. Screening for the Lynch syndrome (hereditary nonpolyposis colorectal cancer). N Engl J Med 2005;352:1851-60.

21 Pinol V, Castells A, Andreu M, Castellvi-Bel S, Alenda C, Llor X, Xicola RM, Rodriguez-Moranta F, Paya A, Jover R, Bessa X. Accuracy of revised Bethesda guidelines, microsatellite instability, and immunohistochemistry for the identification of patients with hereditary nonpolyposis colorectal cancer. JAMA 2005;293:1986-94.

22 Wiinen JT, Vasen HF, Khan PM, Zwinderman AH, van der KH, Mulder A, Tops C, Moller P, Fodde R. Clinical findings with implications for genetic testing in families with clustering of colorectal cancer. N Engl J Med 1998;339:51 1-18.

23 Chen S, Wang W, Lee S, Nafa K, Lee J, Romans K, Watson P, Gruber SB, Euhus D, Kinzler KW, Jass J, Gallinger S, Lindor NM, Casey G, Ellis N, Giardiello FM, Offit K, Parmigiani G. Prediction of germline mutations and cancer risk in the Lynch syndrome. JAMA 2006;296:1479-87.

24 Barnetson RA, Tenesa A, Farrington SM, Nicholl ID, Cetnarskyj R, Porteous ME, Campbell H, Dunlop MG. Identification and survival of carriers of mutations in DNA mismatch-repair genes in colon cancer. N Engl J Med 2006;354:2751-63.

25 Scartozzi M, Bianchi F, Rosati S, Galizia E, Antolini A, Loretelli C, Piga A, Bearzi I, Cellerino R, Porfiri E. Mutations of $h M L H 1$ and $h M S H 2$ in patients with suspected hereditary nonpolyposis colorectal cancer: correlation with microsatellite instability and abnormalities of mismatch repair protein expression. $J$ Clin Oncol 2002;20:1203-8.

26 Engel C, Forberg C, Holinski-Feder E, Pagenstecher C, Plaschke J, Kloor M, Poremba C, Pox CP, Ruschoff J, Keller G, Dietmaier W, Rummele P, Friedrichs N, Mangold E, Buettner R, Schackert HK, Kienle P, Stemmler S, Moeslein G, Loeffler M, German HNPCC consortium. Novel strategy for optimal sequential application of clinical criteria, immunohistochemistry and microsatellite analysis in the diagnosis of hereditary nonpolyposis colorectal cancer. Int J Cancer 2006;118:115-22.

27 Southey MC, Jenkins MA, Mead L, Whitty J, Trivett M, Tesoriero AA, Smith LD, Jennings K, Grubb G, Royce SG, Walsh MD, Barker MA, Young JP, Jass JR, S John DJ, Macrae FA, Giles GG, Hopper JL. Use of molecular tumor

characteristics to prioritize mismatch repair gene testing in early-onset colorectal cancer. J Clin Oncol 2005;23:6524-32.

28 Niessen RC, Berends MJ, Wu Y, Sijmons RH, Hollema H, Ligtenberg MJ, de Walle HE, de Vries EG, Karrenbeld A, Buys CH, van der Zee AG, Hofstra RM Kleibeuker $\mathrm{JH}$. Identification of mismatch repair gene mutations in young colorectal cancer patients and patients with multiple HNPCC-associated tumours. Gut 2006;55:1781-8.

29 de Jong AE, van Puijenbroek M, Hendriks $Y$, Tops $C$, Wijnen J, Ausems MG, Meijers-Heijboer H, Wagner A, van Os TA, Brocker-Vriends AH, Vasen HF, Morreau $\mathrm{H}$. Microsatellite instability, immunohistochemistry, and additional PMS2 staining in suspected hereditary nonpolyposis colorectal cancer. Clin Cancer Res 2004;10:972-80.

30 Domingo E, Niessen RC, Oliveira C, Alhopuro P, Moutinho C, Espin E, Armengol M, Sijmons RH, Kleibeuker JH, Seruca R, Aaltonen LA, Imai K, Yamamoto H, Schwartz S Jr, Hofstra RM. BRAF-V600E is not involved in the colorectal tumorigenesis of HNPCC in patients with functional MLH1 and MSH2 genes. Oncogene 2005;24:3995-8.

31 de Leeuw WJ, Dierssen J, Vasen HF, Wijnen JT, Kenter GG, Meijers-Heijboer H, Brocker-Vriends A, Stormorken A, Moller P, Menko F, Cornelisse CJ, Morreau H. Prediction of a mismatch repair gene defect by microsatellite instability and immunohistochemical analysis in endometrial tumours from HNPCC patients. J Pathol 2000;192:328-35.

32 de Jong AE, Morreau H, van Puijenbroek M, Eilers PH, Wijnen J, Nagengast FM Griffioen G, Cats A, Menko FH, Kleibeuker JH, Vasen HF. The role of mismatch repair gene defects in the development of adenomas in patients with HNPCC. Gastroenterology 2004; 126:42-8.

33 Love RR, Morrissey JF. Colonoscopy in asymptomatic individuals with a family history of colorectal cancer. Arch Intern Med 1984;144:2209-11.

34 Mecklin JP, Jarvinen HJ, Aukee S, Elomaa I, Karjalainen K. Screening for colorectal carcinoma in cancer family syndrome kindreds. Scand J Gastroentero 1987;22:449-53

35 Vasen HF, Hartog Jager FC, Menko FH, Nagengast FM. Screening for hereditary non-polyposis colorectal cancer: a study of 22 kindreds in The Netherlands. Am J Med 1989:86:278-81.

36 Vasen HF, Taal BG, Nagengast FM, Griffioen G, Menko FH, Kleibeuker JH, Offerhaus GJ, Meera KP. Hereditary nonpolyposis colorectal cancer: results of long-ferm surveillance in 50 families. Eur J Cancer 1995;31A:1145-8.

37 Jarvinen HJ, Mecklin JP, Sistonen P. Screening reduces colorectal cancer rate in families with hereditary nonpolyposis colorectal cancer. Gastroenterology 1995; 108:1405-11.

38 Jarvinen HJ, Aarnio M, Mustonen $\mathrm{H}$, Aktan-Collan K, Aaltonen LA, Peltomaki $\mathrm{P}$ de la Chapelle A, Mecklin JP. Controlled 15-year trial on screening for colorectal cancer in families with hereditary nonpolyposis colorectal cancer. Gastroenterology 2000; 1 18:829-34.

39 Renkonen-Sinisalo L, Aarnio M, Mecklin JP, Jarvinen HJ. Surveillance improves survival of colorectal cancer in patients with hereditary nonpolyposis colorectal cancer. Cancer Detect Prev 2000;24:137-42.

40 Arrigoni A, Sprujevnik T, Alvisi V, Rossi A, Ricci G, Pennazio M, Spandre M, Cavallero M, Bertone A, Foco A, Rossini FP. Clinical identification and long-term surveillance of 22 hereditary non-polyposis colon cancer Italian families. Eur J Gastroenterol Hepatol 2005;17:213-19.

41 de Vos tot Nederveen Cappel WH, Nagengast FM, Griffioen G, Menko FH Taal BG, Kleibeuker JH, Vasen HF. Surveillance for hereditary nonpolyposis 
colorectal cancer: a long-term study on 114 families. Dis Colon Rectum 2002;45: 1588-94.

42 de Jong AE, Hendriks YM, Kleibeuker JH, de Boer SY, Cats A, Griffioen G Nagengast FM, Nelis FG, Rookus MA, Vasen HFA. Shift in mortality due to surveillance in the Lynch syndrome. Gastroenterology 2006;130:665-71.

43 Stormorken AT, Clark N, Grindedal E, Maehle L, Moller P. Prevention of colorectal cancer by colonoscopic surveillance in families with hereditary colorectal cancer. Scand J Gastroenterol 2007. In press.

44 de Jong AE, Nagengast FM, Kleibeuker JH, van de Meeberg PC, van Wijk HJ, Cats A, Griffioen G, Vasen HF. What is the appropriate screening protocol in Lynch syndrome? Fam Cancer 2006;5:373-8.

45 Lindor NM, Rabe K, Petersen GM, Haile R, Casey G, Baron J, Gallinger S, Bapat B, Aronson M, Hopper J, Jass J, LeMarchand L, Grove J, Potter J, Newcomb P, Terdiman JP, Conrad P, Moslein G, Goldberg R, Ziogas A, AntonCulver $H$, de Andrade M, Siegmund K, Thibodeau SN, Boardman LA, Seminara D. Lower cancer incidence in Amsterdam-I criteria families without mismatch repair deficiency: familial colorectal cancer type X. JAMA 2005;293:1979-85.

46 Dove-Edwin I, de Jong AE, Adams J, Mesher D, Lipton L, Sasieni P, Vasen HF, Thomas HJ. Prospective results of surveillance colonoscopy in dominant familial colorectal cancer with and without Lynch syndrome. Gastroenterology 2006;130:1995-2000.

47 Dove-Edwin I, Boks D, Goff S, Kenter GG, Carpenter R, Vasen HF, Thomas HJ. The outcome of endometrial carcinoma surveillance by ultrasound scan in women at risk of hereditary nonpolyposis colorectal carcinoma and familial colorectal carcinoma. Cancer 2002;94:1708-12.

48 Rijcken FE, Mourits MJ, Kleibeuker JH, Hollema H, van der Zee AG. Gynecologic screening in hereditary nonpolyposis colorectal cancer. Gynecol Oncol 2003:91:74-80.

49 Renkonen-Sinisalo L, Butzow R, Leminen A, Lehtovirta P, Mecklin JP, Jarvinen HJ. Surveillance for endometrial cancer in hereditary nonpolyposis colorectal cancer syndrome. Int J Cancer 2007;120:821-4.

50 Schmeler KM, Lynch HT, Chen LM, Munsell MF, Soliman PT, Clark MB, Daniels MS, White KG, Boyd-Rogers SG, Conrad PG, Yang KY, Rubin MM, Sun CC, Slomovitz BM, Gershenson DM, Lu KH. Prophylactic surgery to reduce the risk of gynecologic cancers in the Lynch syndrome. N Engl J Med 2006;354:261-9.
51 Weber T. Clinical surveillance recommendation adopted for HNPCC. Lancet 2006:348:465

52 de Vos tot Nederveen Cappel WH, Buskens E, van Duijvendijk P, Cats A, Menko FH, Griffioen G, Slors JF, Nagengast FM, Kleibeuker JH, Vasen HF. Decision analysis in the surgical treatment of colorectal cancer due to a mismatch repair gene defect. Gut 2003;52:1752-5

53 Carethers JM, Chauhan DP, Fink D, Nebel S, Bresalier RS, Howell SB, Boland CR. Mismatch repair proficiency and in vitro response to 5-fluorouracil. Gastroenterology 1999;117:123-31.

54 Jacob S, Aguado M, Fallik D, Praz F. The role of the DNA mismatch repair system in the cytotoxicity of the topoisomerase inhibitors camptothecin and etoposide to human colorectal cancer cells. Cancer Res 2001;61:6555-62.

55 Liang JT, Huang KC, Lai HS, Lee PH, Cheng YM, Hsu HC, Cheng AL, Hsu CH, Yeh KH, Wang SM, Tang C, Chang KJ. High-frequency microsatellite instability predicts better chemosensitivity to high-dose 5-fluorouracil plus leucovorin chemotherapy for stage IV sporadic colorectal cancer after palliative bowe resection. Int J Cancer 2002;101:519-25.

56 Ribic CM, Sargent DJ, Moore MJ, Thibodeau SN, French AJ, Goldberg RM, Hamilton SR, Laurent-Puig P, Gryfe R, Shepherd LE, Tu D, Redston M, Gallinger S. Tumor microsatellite-instability status as a predictor of benefit from fluorouracilbased adjuvant chemotherapy for colon cancer. N Engl J Med 2003;349:247-57

57 Carethers JM, Smith EJ, Behling CA, Nguyen L, Tajima A, Doctolero RT, Cabrera BL, Goel A, Arnold CA, Miyai K, Boland CR. Use of 5-fluorouracil and survival in patients with microsatellite-unstable colorectal cancer. Gastroenterology 2004; 126:394-401.

58 de Vos tot Nederveen Cappel WH, Meulenbeld HJ, Kleibeuker JH, Nagengast FM, Menko FH, Griffioen G, Cats A, Morreau H, Gelderblom H, Vasen HF. Survival after adjuvant 5-FU treatment for stage III colon cancer in hereditary nonpolyposis colorectal cancer. Int J Cancer 2004; 109:468-71.

59 Fallik D, Borrini F, Boige V, Viguier J, Jacob S, Miquel C, Sabourin JC, Ducreux M, Praz F. Microsatellite instability is a predictive factor of the tumor response to irinotecan in patients with advanced colorectal cancer. Cancer Res 2003;63:5738-44.

60 Hurlstone DP, Karajeh M, Cross SS, McAlindon ME, Brown S, Hunter MD, Sanders DS. The role of high-magnification-chromoscopic colonoscopy in hereditary nonpolyposis colorectal cancer screening: a prospective "back-toback" endoscopic study. Am J Gastroenterol 2005;100:2167-73.

\section{See your work published in Journal of Medical Genetics}

Journal of Medical Genetics is only as good as its articles, so we work hard to support the authors who trust us to publish their work. Here are just a few reasons why you should send us your article:

- Academic credibility - You'll be published in one of the top medical genetics journals in Europe.

- Maximum visibility for your article - Your work will be seen by a wide international audience, both through the print journal (C 1500 readers per issue) and the website ( $\sim 2,000$ unique visitors every month).

- Hassle free peer review - Our fast and efficient submission process involves only the best reviewers. The entire submission and peer review process is conducted online, saving you time and shortening the wait for your paper to be published.

- Online First - Your article may appear on the journal website as soon as it's accepted via our 'Online First' feature. Your colleagues could be reading your paper within days of you submitting it.

For more information or to submit an article visit www.jmg.bmj.com and click the Online Submissions button. 